Global Conferences Series:

Sciences and Technology (GCSST), Volume 3, 2020

The $1^{\text {st }}$ International Conference on Education, Sciences and Technology

DOI: https://doi.org/10.32698/tech3235

\title{
Analysis of industrial needs for job seekers
}

\author{
Muhammad Yahya ${ }^{1 *}$, Yasdin ${ }^{1}$, Andi Muadz ${ }^{1}$, Andi Zulfikar Yusuf ${ }^{1}$, and \\ Bakhrani Rauf ${ }^{1}$ \\ ${ }^{1}$ Universitas Negeri Makassar, Indonesia \\ *m.yahya@unm.ac.id
}

\begin{abstract}
The problem in this article focuses on the demands of an increasingly complex industry in the era of rapid Increasingly technology. Job seekers have not been able to adjust quickly intervening to keep up with technological developments. This article aims to find out: (1) the level of labor absorption in the employment sector and (2) the needs of the industry for job seekers. Using the Pacto exposure research method with a descriptive approach. The research sample of the workforce and industry involved in Makassar. The research instrument used documentation, interview guidelines and questionnaires. The collected Data was analyzed using descriptive statistics. The results of the study show that the information of the job seekers are very decisive in mapping the needs of employment and industries requiring employ ability skills from job seekers.
\end{abstract}

Keywords: Analysis, Needs, Industry, Labor

\section{Introduction}

Indonesia is faced with four labor sector competition, namely (1) the problem of qualifications and competencies of the Indonesian workforce (Q. Rostanti), (2) second, Indonesia's economic growth in the second quarter of 2015 was 4.67 percent, while the economic growth target for 2016 it is expected to reach 5.1 percent which has implications for job vacancies, (3) as the ASEAN Economic Community (AEC) implements, which means that it will be wide open to transfer people to work from other countries. If the competent workforce will be a golden opportunity for workers to compete with workers from other countries (H. Dhakiri) and (4) is the demographic bonus that occurs in Indonesia in 2020 until 2030, where the Indonesian population will be needed by productive age population.

The results of the study in 2017 showed, one of the main problems faced by workers in the city of Makassar is the difficulty of finding employment. Data downy mildew in May 2017 by $14.5 \%$ and $14.3 \%$ November (Agency for Regional Research and Development Makassar City, 2017). Such conditions could potentially cause urban problems into social issues of concern (Ermida).Although job seekers' reputation perceptions may be based on different factors than other constituents (e.g., investors, consumers), we know little about the antecedents of job seekers' reputation perceptions (D.M. Cable and M.E. Graham). Most of this apparent decline results from changes in the composition of job-seekers (R.E. Hall and S.S. Wohl).

Copyright (C) 2019, the Authors. Published by Redwhite Press. 
Labor issues require in-depth mapping. The research result Sunartono showed that (1) demand for educated labor force faster than the demand for labor as a whole, (2) demand for educated labor force faster than the labor supply of educated, and (3) both of these implications for the increasing inequality wages, and the scarcity of labor demand is not met, and that is surprising is the number of educated unemployed is relatively high, especially in urban areas.Recruitment advertisements are one of the first sources used by job seekers to gather organi- zational information that influences the formation of initial organizational perceptions (A.E. Barber \&M.V. Roehling; J.A. Breaugh).

There are many factors that influence the absorption of labor one of which is employment. According Esmara, employment opportunities can be interpreted as the number of people who work or those who had already been employed, more and more people working more and more extensive employment opportunities. Employment as a field of business or employment opportunities that have been available for work as a result of an economic activity, thus employment includes the completed jobs and employment opportunities can also be interpreted as participation in development (H.S. Sagir).

Provide an understanding of employment as a situation where all workers who want to work at a certain wage level will easily get a job (S. Sukirno). Competence as' knowledge, skills or abilities of any individual who exhibited referred to as competence (H. Pamlian and T. Nuriana). Competence is a pattern of knowledge, skills, abilities, behavior and other characteristics can be measured as required by a person to do the job role or job function properly (Jackson et al). Some think it shows that employment is the productive age population who are having a job or do not have a job or are looking for work. Job seekers increased their active job search behavior, formal job-source usage, and search intensity and decreased their job-search anxiety (A.M. Saks and B.E. Ashforth).

Competence is an important requirement that must be owned labor to competence with other workers. Indonesian labor conditions are still under the competence of foreign labor. An important requirement which must be owned by Indonesian workers in competing are as follows; (1) level of education equivalent to foreign labor, (2) the skill which is equivalent to foreign labor, and (3) the length of working together with foreign labor (F.B. Randang).

\section{Methods}

This research is ex post facto with a descriptive approach that tried to give an overview and description of employment issues in the city of Makassar. The population in this study include all services within the scope of Makassar, the employment sector, and business and industry. The research sample involving related agencies, five employment sectors, and business and industry taken by using purposive. The research was conducted in Makassar, from May to October 2018.Instrument used in this study are; documentation, interviews, and questionnaires. Data collected were analyzed using descriptive statistics. 


\section{Results and Discussion}

Based from the research result, researcher found date follow table 1 below.

Table 1. Job seekers condition

\begin{tabular}{|c|c|c|c|c|c|c|c|}
\hline \multirow{3}{*}{ No } & \multirow{3}{*}{ Group } & \multicolumn{6}{|c|}{ Years-Month } \\
\hline & & \multicolumn{2}{|c|}{2015 (Jan-Dec) } & \multicolumn{2}{|c|}{2016 (Jan-Dec) } & \multicolumn{2}{|c|}{2017 (Jan-Dec) } \\
\hline & & $\mathbf{M}$ & $\mathbf{F}$ & $\mathbf{M}$ & $\mathbf{F}$ & $\mathbf{M}$ & $\mathbf{F}$ \\
\hline 1 & Job seekers & 39.52 & 38.60 & 30.27 & 26.78 & 43.34 & 40.42 \\
\hline 2 & Job vacancy & 10.46 & 12.74 & 29.09 & 27.73 & 24.21 & 23.60 \\
\hline 3 & $\begin{array}{l}\text { Employmen } \\
\text { placement }\end{array}$ & 6.07 & 6.21 & 25.04 & 24.36 & 19.78 & 21.21 \\
\hline 4 & $\begin{array}{l}\text { Elimination of job } \\
\text { seekers }\end{array}$ & 2.88 & 1.96 & 5.78 & 7.42 & 7.89 & 9.99 \\
\hline & Quantity & 58.93 & 59.51 & 90.18 & 86.29 & 95.22 & 95.22 \\
\hline & Job seekers quantity & \multicolumn{2}{|c|}{78.12} & \multicolumn{2}{|c|}{57.07} & \multicolumn{2}{|c|}{83.76} \\
\hline & ob seekers placement & \multicolumn{2}{|c|}{14.74} & \multicolumn{2}{|c|}{49.40} & \multicolumn{2}{|c|}{40.99} \\
\hline Eli & mination of job seekers & \multicolumn{2}{|c|}{22.28} & \multicolumn{2}{|c|}{13.20} & \multicolumn{2}{|c|}{17.88} \\
\hline & ob seekers not placed & \multicolumn{2}{|c|}{83.15} & \multicolumn{2}{|c|}{77.60} & \multicolumn{2}{|c|}{102.49} \\
\hline & Job seekers & \multicolumn{2}{|c|}{2014 (149.66) } & \multicolumn{2}{|c|}{$2015(83.15)$} & \multicolumn{2}{|c|}{$2016(77.60)$} \\
\hline
\end{tabular}

Tabel 2. Job seeker based on age

\begin{tabular}{llcccccc}
\hline \multirow{2}{*}{ No } & \multirow{2}{*}{ Group Based Age } & \multicolumn{7}{c}{ Years-Month } \\
\cline { 3 - 8 } & & $\mathbf{2 0 1 5}$ (Jan-Dec) & $\mathbf{2 0 1 6}$ (Jan-Dec) & $\mathbf{2 0 1 7}$ (Jan-Dec) \\
\cline { 3 - 8 } & $\mathbf{M}$ & $\mathbf{F}$ & $\mathbf{M}$ & $\mathbf{F}$ & $\mathbf{M}$ & F \\
\hline 1 & $10-14$ & 0.00 & 0.00 & 0.00 & 0.00 & 0.00 & 0.00 \\
2 & $15-19$ & 6.61 & 6.43 & 6.70 & 5.70 & 9.81 & 8.34 \\
3 & $20-29$ & 20.36 & 19.98 & 16.78 & 14.68 & 25.83 & 26.62 \\
4 & $30-44$ & 12.17 & 11.94 & 6.31 & 5.80 & 7.48 & 5.33 \\
5 & $45-54$ & 0.38 & 0.25 & 0.48 & 0.60 & 0.22 & 0.13 \\
6 & $>55$ & 0.00 & 0.00 & 0.00 & 0.00 & 0.00 & 0.00 \\
\hline \multicolumn{2}{c}{ Total } & $\mathbf{3 9 . 5 2}$ & $\mathbf{3 8 . 6 0}$ & $\mathbf{3 0 . 2 7}$ & $\mathbf{2 6 . 7 8}$ & $\mathbf{4 3 . 3 4}$ & $\mathbf{4 0 . 4 2}$ \\
\hline
\end{tabular}

Based on the data of job seekers according to the principal office of the group class, the dominant professional group interested applicants and occupies the first place of the group of base class positions, with the number of job seekers as much as 6758 or $45.82 \%$, consisting of men and women 3379. Then comes a group manager with the number of job seekers as much as in 2240, or $15.19 \%$ consisting of 1017 men and 1223 women. The finding relevant of Sunartonoargued. He showed demand for educated labor force faster than the demand for labor as a whole.

Labor groups and business services sales, the number of job seekers as much as 1306 or $8.85 \%$, consisting of 607 men and women 699 . Neither the clerical group, the number of job seekers in 1155 , or $7.83 \%$, consisting of 601 men and 554 women and a group of professional technicians and assistantswith the number of job seekers as much as 1115 or $7.56 \%$ comprising 587 men and 528 women.Gender was found to moderate the use of 
utterances and employment-related recommendations in an unexpected direction for women (J.A. Harrison and M.H. Budworth).

For groups of workers craft processing, the number of job seekers as much as 610 or $4.14 \%$, consisting of 356 men and 254 women, machine operators and assemblers to 580, or $3.93 \%$, consisting of 271 men and 309 women. Skilled workers, agriculture, forestry and fisheries 570 or $3.86 \%$, consisting of 267 men and 303 women workers rugged 415 or $2.81 \%$, consisting of 202 men and 213 women from the total number that 14749 job seekers. Recent graduates differ in many ways from employed and unemployed job seekers (A.E. Barber et al.; D.P. Schwab et al).

Based on data from 2016, about the results of job seekers according to the principal office of the group class, the dominant professional group interested applicants and occupies the first place of the group of base class positions, with the number of job seekers as much as in 2274 , or $39.86 \%$ were composed of men by 1178 and 1096. Then comes a group of women clerical workers with the number of job seekers as much as 758 or $13.29 \%$, consisting of 391 men and 367 women.

Labor groups and business services sales, the number of job seekers as much as 564 or $9.89 \%$, consisting of 291 men and 273 women group of skilled workers, agriculture, forestry and fisheries, with the number of job seekers as much as 526 or $9.22 \%$ of consisting of 317 men and 209 women, a group of professional technicians and assistants with the number of job seekers as much as 472 or $8.27 \%$, consisting of 260 men and 212 women.

Meanwhile, a group manager with the number of job seekers as much as 463 or $8.12 \%$ comprising 224 men and 239 women handicraft processing trade group, the number of job seekers as much as 262 or $4.59 \%$, consisting of 143 men and 119 women. Operators and assemblers machines as 221 , or $3.87 \%$, consisting of 134 men and 187 women, manual workers or $2.89 \%$ sebanyak165 comprising 89 men and 76 women from the 5705 total number of job seekers.

In 2017 data from job seekers according to the base class group of office showed the dominant professional groups interested in and occupy the first order of applicants job seekers, the number of job seekers as much as in 2405 , or $28.71 \%$ were composed of 1210 men and women 1195. Furthermore, following a clerical power group with the number of job seekers in 1519 or $18.14 \%$ consisting of as many as 685 men and 834 women.

While labor groups and business services sales, the number of job seekers as much as in 1377 , or $16.44 \%$ consisting of as many as 565 men and women 812 . Neither group of professional technicians and assistants, with the number of job seekers 927 or $11.07 \%$, consisting of as many as 583 men and 344 women, a group manager with the number of job seekers 881 or $10.52 \%$, consisting of 47 men and 411 women. The results show that lack of institutional interactions, socially constructed norms that influence graduates' perceptions and ambiguous directions of educational policies significantly affect university graduates' employment (S. Ren, Y. Zhu and M. Warner).

The next group of skilled workers with job seekers as much as 470 or $5.61 \%$ comprising 289 men and 181 women groups and craft processing workers, the number of work seekers by 334 or $3.99 \%$, consisting of as many men as 217 and 117 . Woman machine operator and assembler of 295 , or $3.52 \%$, consisting of 178 men and 117 women, manual workers by 168 or $2.01 \%$ consisted of 137 men and 31 women from the number the 8376 total job seekers.As well, because the use of informal sources is stressful and requires social skills and strong self-esteem (A.E Barber et al.; R.A. Ellis \&M.S. Taylor).

The data shows that in the last three principal groups of the most desirable positions is a professional group. The information job seekers in Makassar also described the condition 
of job seekers. Describes the results of interviews conducted business world and industry response to employment seekers. Human Resource Development to explain some of the obstacles faced by job seekers. The condition can be described simply in Table 3 below.

Table 3.

Reality Job Seekers

\begin{tabular}{cl}
\hline No. & \multicolumn{1}{c}{ Reality Job Seekers } \\
1 & The ability of job seekers less \\
2 & Job seekers rely on diploma \\
3 & Still require further training \\
4 & The desire to work a little \\
5 & Prefers salary \\
6 & Less mamu work on target \\
7 & Less able to work under pressure \\
8 & Quickly bored at work \\
\hline
\end{tabular}

Source: Department of Labor and Transmigration Makassar, 2018

The data obtained also show that the business world and the industry needs a strong and good mental than job seekers. The results showed that the world industry interview more emphasis on character and strong soft skills of job seekers. Industrial realized that the hard skills of job seekers can be forged through training. Industries needed job seekers know to to develop companies a consistent communication strategy (K. Klimkiewicz and V. Oltra). S. Pajic et al. draw on career construction theory to examine whether refugees' adaptive readiness, captured by their psy- chological capital, is positively related to job search selfefficacy through the mediating mechanism of career adaptability. Job seekers' provide insights, understanding, and inspiration (A. Newman). Organization always been concerned with attracting and selecting the right types employees (S.L. Rynes\& A.E Barber; B. Schneider). It is widely acknowledged that highly qualified employees are beneficial to the creation of competitive advantage (T.H. Cox \& S. Blake; P.M. Wright, B.B. Dunford, \& S.A. Snell).While some studies on job seeker attraction have examined mediators such as anticipated organizational support and anticipated role performance ( W.J.Casper \&L.J. Buffardi; J.H. Wayne \&W.J. Casper).

\section{Conclussion}

Based on research that has been done we can conclude several things; 1) The information job seekers will determine employment work need mapping; 2) the level of education determines labor in various midwife; and 3) business and industry require employ ability skills of job seekers. The finding of research showing more emphasis on character. Industries needed strong soft skills of job seeker not just a hard skills and competencies. Industries need job seeker soft skills than the hard skill. Job seekers' must know uncertainty and changing in the world of work.

\section{References}

[1] A.E. Barber, Giannantonio, and J. M. Philips, "Job search activities: An examination of changes over time”, Personnel Psychology, 47, 1994, pp 739-765. 
[2] A.E. Barber, \& M.V. Roehling, "Job postings and the decision to interview: A verbal protocol analysis", Journal of Applied Psychology, 78, 1993, pp 845-856.

[3] A.M. Saks and B.E. Ashforth, "Change in Job Search Behaviors and Employment Outcomes", Jurnal of Vocational Behaviour, vol 56, 2000, pp 277-287.

[4] A. Newman, "Vocational Behavior of Refugees: How do Refugees Seek T Employment, Overcome Work-related Challenges, and Navigate Their Careers?', Journal of Vocational Behaviour, No 105, 2018, pp 1-5.

[5] B. Schneider, "The people make the place", Personnel Psychology, 40, 1987, pp 437453.

[6] D. M. Cable and M.E. Graham, "The determinant of job seekers' reputation perception", Journal of Organizational Behaviour, vol 21, no 21, May 2000, pp 929-947.

[7] D. P.Schwab et al,"Theories and research on job search and choice. In K. M. Rowland \& G. R. Ferris (Eds.)", Research in personnel and human resources management, Vol. 5, 1987, pp. 129-166.

[8] Esmara,Human Resources, Employment and Economic Development. Jakarta: UI Press Jakarta, 1986.

[9] F.B.Randang,"Indonesian workforce readiness in facing the competition of foreign labor",Servanda Scientific Journal of Laws, Volume 5, Number 1,2011, pp 66-73.

[10] H. Pamlian and T. Nuriana, Competence Plus. Jakarta: PT GramediaPustaka Utama, 2008.

[11] H.S.Sagir,Build-Problems of Human Work Employment and Human Resources Development . Jakarta: PustakaSinar expectations Jakarta, 1989.

[12] J.A. Breaugh, "Employee recruitment: Current knowl- edge and important areas for future research", Human Resource Management Review, 18, 2008, pp 103-118.

[13] J.A. Harrison and M.H.Budworth, "Unintended consequences of a digital presence :Employment-related implications for job seekers", Career Development International, Vol. 20,Iss 4, February 2016, pp. $294-314$.

[14] J.H. Wayne, \& W.J. Casper, "Why does firm reputation in human resource policies influence college students?The mechanisms underlying job pursuit intentions", Human Resource Management, 51, 2012, pp 121-142.

[15] K. Klimkiewicz and V. Oltra, "Does CSR Enhance Employer Attractiveness? The Role of Millennial Job Seekers' Attitudes", Corporate Social Responsibility and Environmental Management, vol 1, no1, 2017, pp-.

[16] P.M. Wright, B.B. Dunford, \& S.A. Snell, S. A., "Human resources and the resource based view of the firm", Journal of Management, 27, 2001, pp 701-721.

[17] R. A. Ellis, \& M. S Taylor, "Role of self-esteem within the job search process",Journal of Applied Psychology, 68, 1983, pp 632-640.

[18] R.E. Hall and S.S. Wohl. "Measuring Job-Finding Rates and Matching Efficiency with Heterogeneous Job-Seekers." American Economic Journal: Macroeconomics, Vol 10, No 1, 2018, pp 1-32.

[19] R.Qommarria, Four Indonesian Labor Sector Challenges, (Republika Imprint Wednesday, 2005, 04 Nov, 2015).

[20] S.L. Rynes, \& A.E Barber, (1990), “Applicant attraction strat- egies: An organizational perspective", Academy of Man- agement Review, 15, 1990, pp 286-310. 
RedWhitepress Gilobal Conferences Series: Scieneres and Technology (GCSST), Volume 3, 2020

[21] S. Pajic et al "Antecedents of job search self-efficacy of Syrian refugees in Greece and theNetherlands".Journalof Behaviorhttp://dx.doi.org/10.1016/j.jvb.2017.11.001.

[22] S. Sukirno,Modern Macroeconomics: the development of thought from classical to new Keynesian. Jakarta: King GrafindoPersada Jakarta, 2000.

[23] Sunartono, "Analysis of increasing employment opportunities in Indonesia", Indonesian Journal of Science and Technology, Vol. 10 No. 1 April 2008,pp. 48-53.

[24] S. Ren, Y. Zhu and M. Warner, "Dilemmas concerning the employment of university graduates in China", Journal of Studies in Higher Education, January 2016, pp 121.

[25] T.H. Cox, \&S. Blake, "Managing cultural diversity: Implications for organizational competitiveness",Academy of Management Executive, 5, 1991, pp 45-56.

[26] W.J. Casper, \& L.J. Buffardi, "Work-life benefits and job pursuit intentions: The role of anticipated organizational support", Journal of Vocational Behavior, 65, 2004, pp 391-410.

\section{Acknowledgments}

We are grateful to our reviewer and editor for their invaluable feedback throughout the review process. We would also like to thank Makassar State University Rectors and Mayor of Makassar City. This study has been partially funded by a research grant from the Department of Labor and Transmigration, Makassar, Indonesia. 